\title{
Description Parenting Pattern of Punk Children in District Bojoneogoro
}

\author{
Siti Patonah*, Agus Ari Afandi \\ Akes Rajekwesi Bojonegoro, Indonesia \\ *sitipatonah73@gmail.com
}

\begin{abstract}
Increasing needs in life makes many parents work continuously so less attention to children. This has an impact on the child will seek outings outside the home, such as to his friends, and even join the punk community. The decision of a child to join the community of punk children is influenced by many families, one of them is parenting pattern. The phenomenon that occurs in society today is an increase in cases of punk children's presence at crossroads. Children punk at the crossroads Bojonegoro District doing activities of smoking and drinking alcohol at night so that the surrounding community feel disturbed and disturbing residents. The purpose of this research is to describe the pattern of parent care in punk children in Bojonegoro District.

This research uses descriptive research type with survey approach with sample number 8 parents who have punk children, sampling technique using total sampling. Variable in this research is parent's parenting pattern in punk child. Methods of data collection by using questionnaires then performed data processing by editing, coding, scoring and tabulating and univariate analysis with frequency distribution.

The results obtained more than the majority of respondents $(62.5 \%)$ implement permissive parenting.

In this case it is expected that parents should always pay attention and affection, and supervise and guidance to the child to avoid misbehavior in punk children's community and apply democratic parenting pattern, where the children are given the opportunity to express their opinions, ideas and wishes so that children participate but there are rules from parents
\end{abstract}

Keywords: Parenting Pattern, Parents, Child, Punk 


\section{STRADA Jurnal Ilmiah Kesehatan}

DOI: $10.30994 /$ sjik.v9i2.305

ISSN: 2252-3847 (print); 2614-350X (online)

Vol.9 No.2 November 2020 Page. 1665-1669

\section{BACKGROUND}

The increasing necessity of life makes parents pay less attention to their children, so that children seek attention outside the home, such as seeking attention from friends and even joining the punk community. The punk community is synonymous with the music and fashion they wear. Punk is not only synonymous with music and fashion style but also synonymous with the ideology they believe in. Many people have negative perceptions about punk by assuming that punk appearance seems "messy", shabby, shabby, and unattractive to look at (Mayasari et al, 2015: 2). The decision of a child to join the punk community is largely influenced by the family. Families, especially parents, have the first influence on children. The parenting style that is applied to children will affect the interaction process between parents and children (Ester, 2013: 4). The phenomenon that occurs in society today is an increase in cases of punk children at crossroads. The punk kids at the crossroads of Bojonegoro sub-district smoke and drink alcohol at night so that the local community feels disturbed and unsettled by residents.

In 2014, there were quite a lot of punk children in the community, namely $25 \%$ of the total population, which is around 70 million people, people aged under 17 years (Ratna, 2014). According to Indrapana in Indonesia, it was recorded that in 2007, there were around $40 \%$ men and $20 \%$ of women who identified themselves as punk children, and there was a surprising increase in 2008, there were $65 \%$ of men who identified themselves as punks. and 52\% of girls who identify themselves as punk children (Mayasari et al, 2015: 2). The Central Statistics Agency (BPS) states that street children who are members of the punk child community at the level of East Java, especially Surabaya, are the cities with the fastest growth of street children, estimated at 1,500 children. According to data from the Bojonegoro Regency Social Service, in the Bojonegoro District in 2016 there were 8 children who were members of the punk community.

Punk is very synonymous with strong togetherness and wants freedom, they help each other between friends, collect cash from singing to help friends who are in trouble or are hit by a disaster, on the other hand they don't want to be regulated, they want to be free with their lives on the road with friends punk (Amalia, 2008: 19). Parenting can be defined as all the ways parents treat children. Many experts say child rearing is an important and fundamental part of preparing children to become good societies (Wahyuning, et al, 2013: 126). In the children's community, most of the families are believed to apply permissive parenting, where parents exercise less control than authoritarian and authoritative parenting because they believe that children should be ready to learn independently because they do not apply discipline to their children. They give freedom to children to consider their free time activity schedule and free to choose activities that their children like. Parents do not demand much respect and are more tolerant of immature behavior in their children (Sari Journal, 2015: 20).

Efforts that can be made to overcome problems in punk children include providing information to families to guide children's behavior by approaching social norms and religious norms, parents must be more prepared to supervise their children who are unstable and underage. their children do not fall prey to bad and inappropriate associations. Providing health education to increase the knowledge of parents and the punk child community about norms that should not be violated in carrying out activities as a punk child (Haryanto, 2012: 4). 


\section{STRADA Jurnal Ilmiah Kesehatan}

DOI: $10.30994 /$ sjik.v9i2.305

ISSN: 2252-3847 (print); 2614-350X (online)

Vol.9 No.2 November 2020 Page. 1665-1669

\section{METHODS}

This study uses a descriptive research design, which is a research method that aims to describe (describe) important events that are happening in the present, carried out systematically and emphasize factual data rather than inferences (Nursalam, 2016: 160). The approach used in this study is a survey, which is a descriptive research method conducted on a group of objects which are usually quite large in a certain period of time (Notoatmodjo, 2010: 140).

Sampling in this study uses a non-probability sampling technique with a total sampling method, namely a sampling technique when all populations are used as samples and it is also known as a census (Sugiyono, 2011: 85).

a. Data Collection Process

After getting a recommendation from the Director of the Rajekwesi Bojonegoro Health Academy, the researcher asked the Bojonegoro District Head for permission to conduct the research. The research was conducted after the proposal was approved by the supervisor and after obtaining permission from the Head of Bojonegoro District. The study began by looking for respondents who fit the inclusion criteria. Furthermore, the researcher provides information about the aims and objectives of the research carried out. If the respondent understands that the researcher will distribute a questionnaire to fill in the general data of the respondent and data about the parenting styles of parents who have punk children

b. Data Collection Instrument

General data uses a questionnaire, namely a list of questions that are well arranged, ripe, where the respondent only needs to give answers or by giving certain signs (Notoatmodjo, 2012: 116). General data consists of family type, age, marital status, education and employment history. The parenting style questionnaire consists of 18 questions, the value of each question is based on the Likert scale guideline.

c. Data analysis

The steps in data processing in this research are: data checking (editing), coding, scoring, data compiling (tabulating).

\section{RESULTS}

Distribution of age characteristics of respondents in Bojonegoro District in 2017.

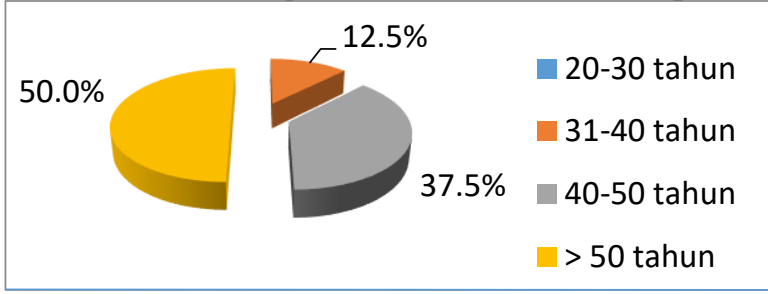

Distribution of the characteristics of the respondent's family types in Bojonegoro District in 2017

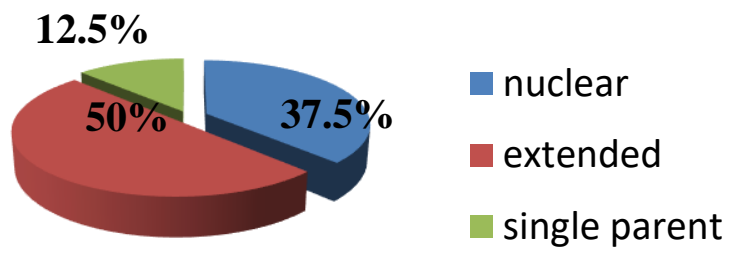

Type of Family 


\section{STRADA Jurnal Ilmiah Kesehatan}

DOI: $10.30994 /$ sjik.v9i2.305

ISSN: 2252-3847 (print); 2614-350X (online)

Vol.9 No.2 November 2020 Page. 1665-1669

Distribution of educational characteristics of respondents in Bojonegoro District in 2017

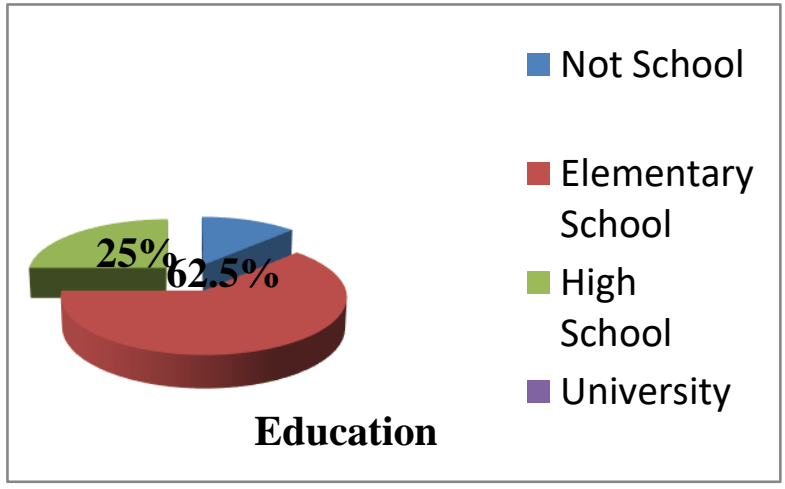

Parenting Patterns of Punk Children in Bojonegoro District in 2017

\begin{tabular}{|l|l|l|l|}
\hline No & Parenting Patterns & Frequency & Persentase (\%) \\
\hline 1. & Democratic & 0 & 0 \\
2. & Authoritarian & 3 & $37,5 \%$ \\
3. & Permissive & 5 & $62,5 \%$ \\
\hline Total & & & \\
\hline
\end{tabular}

\section{DISCUSSION}

The results showed that more than half of the respondents practiced permissive parenting.

In theory, in the punk community, most of the families are believed to apply permissive parenting. In principle, child rearing is an important and fundamental part of preparing children to become good societies (Wahyuning, et al, 2013: 126). Permissive parenting is a type of parenting that is ignorant of children. So whatever the child will do is allowed such as not going to school, being naughty, doing a lot of immoral activities, negative promiscuity, materialism. The parenting style of permissive parents is too lenient, helpless, gives freedom to children without any norms that must be followed by them (Ester, 2013: 7-9).

According to the opinion of researchers that more than some punk children go through permissive parenting, this is in line with the theory that in the punk community, most of the families are believed to apply permissive parenting, where parents exercise less control than authoritarian and authoritative parenting because they believe that children must be ready to learn independently because they do not apply discipline to their children. They give freedom to children to consider their free time activity schedule and free to choose activities that their children like. Parents do not demand much respect and are more tolerant of immature behavior in their children (Sari, 2015: 20). Some of the respondents aged $>50$ years have theoretically maturity and readiness to educate their children, but this is not in accordance with the theory, this may be due to other factors such as the environment. More than some of the respondents have basic education (SD, SMP) this is in accordance with the theory because after all the education and experience of parents in child care will affect their readiness to carry out parenting roles.

The solution that needs to be given to overcome the existence of punk children is to provide counseling carried out by the social service in collaboration with the health office for both parents and children so that the activities carried out by children can lead to positive 


\section{STRADA Jurnal Ilmiah Kesehatan}

DOI: $10.30994 /$ sjik.v9i2.305

ISSN: 2252-3847 (print); 2614-350X (online)

Vol.9 No.2 November 2020 Page. 1665-1669

things and not harm themselves or the surrounding environment. provide information to families to guide children's behavior by approaching prevailing social and religious norms so that children can avoid deviant behavior in the punk community, parents must be better prepared to supervise their children who are unstable and underage so that their children do not fall into bad associations and are not in accordance with the negative behavior of the punk child community.

\section{CONCLUSION}

More than some of the respondents $(62.5 \%)$ practice permissive parenting. In this case it is expected that parents always give attention and affection, as well as supervise and guide children to avoid deviant behavior in the punk child community and apply democratic parenting. , where children are given the opportunity to express their opinions, ideas and desires so that children participate, but there are still rules from parents

\section{REFERENCES}

Amalia. 2008. Konsep Diri Remaja Punk.

http://psychology.uii.ac.id/images/stories/jadwal_kuliah/naskah-publikasi-

04320142.pdf. Diakses tanggal 1 januari 2017

Damaiyanti. 2012. Asuhan Keperawatan Jiwa. Refika Aditama. Bandung.

Fitri et al. 2010. Hubungan Kesiapan Psikologis. http://www.untb.ac.id. Diakses tanggal 12

Desember 2016

Fikriyati. 2013. Perkembangan Anak Usia Emas. Yogyakarta : Laras Media Prima

Hendriyanto \& Handayani .2013. Motivasi anak memilihanggota punk. http://administrasipublik.studentjournal.ub.ac.id/index.php/jap/article/viewFile/90/

81. Diakses tanggal 23 Desember 2016.

Mayasari et al. 2015. Anak punk.http://perpusnwu.web.id/karya ilmiah/docum.ents/4540.pdf. Diakses tanggal 13 Nopember 2016

Nursalam. 2013. Konsep dan Penerapan Metodologi Penelitian Ilmu Keperawatan. Jakarta : Salemba medika

Sugiyono. 2012. Metode Penelitian Kuantitatif, Kualitatif, dan R\&D. Bandung: AFABETA. 